\title{
Folkebiblioteket som formidler af samfundsinformation
}

\author{
Af Marianne Hummelshøj
}

\section{Indledning}

Folkebibliotekerne har altid formidlet samfundsinformation, men i slutningen af 70'erne blev der sat særlig fokus på bibliotekernes formidling af den lokale offentlige information, da flere biblioteker, bl.a. Lyngby indgik $i$ et samarbejde med de kommunale institutioner. I modsætning hertil blev der f.eks. i København etableret en kommuneinformation direkte under den kommunale forvaltning. I bibliotekskredse blev især betydningen af uafhængigheden af de kommunale myndigheder diskuteret $i$ relation til borgernes frie adgang til information. Det drejede sig om deres muligheder for adgang til information, som ikke nødvendigvis afspejlede myndighedernes opfattelse. På baggrund af denne diskussion og flere offentlige betænkninger fik bibliotekets formidling af samfundsinformation ${ }^{1}$ en central rolle i biblioteksloven ${ }^{2}$ Folkebibliotekerne har arbejdet ud fra nedenstående definition af samfundsinformation(1):
* Offentlig information

* produceret af statslige, amtskommunale og kommunale myndigheder

Eks: Kommunekemi, Patentdirektoratet

* Ikke-offentlig information

* produceret af borgere uden tilknytning til myndigheder

* formål: at oplyse og påvirke samfundsforhold

Eks: Kræftens bekæmpelse, Dansk Cyklistforbund

* Alternativ information

* produceret af græsrodsbevægelser

* formål: kritik $\rightarrow$ samfundsforandring

Eks: Greenpeace, Folkebevægelsen mod

Unionen

* Modinformation

* produceret af borgere

* formål: fremlægge synspunkter i en aktuel debat og påvirke beslutningsgrundlaget

Eks: skolenedlæggelser, brobygninger 


\section{Samfundsinformation i folkebiblioteket}

Opgaven har de fleste steder været løst som det vil fremgå af følgende grovskitse. Tilsendt gratis informationsmateriale fra bl.a. Statens Information er blevet fremlagt på passende steder til publikum, enkelte steder er ét eksemplar blevet registreret og anbragt $i$ en systematisk orden, som regel efter DK5, hvilket gav bibliotekarerne både en aktuel oversigt over det fremlagte og en mulighed for at lette genbestilling. Den kommunale information bestod som regel af dagsordner og referater fra kommunalbestyrelse/ byråd, hertil kom kommuneplan og planer for specifikke områder, f. eks. skoler og miljø. Baggrunden for udarbejdelsen af disse planer var et krav ved kommunalreformen i 1970. Disse materialer blev fremlagt sammen med lokalplansforslag og andet informationsmateriale fra kommunen i "det kommunale hjørne", normalt kun til gennemsyn på stedet. I tilknytning hertil blev amtslig information og f.eks. Folketingets dagsordener ligeledes præsenteret uden for den normale opstilling af bibliotekets materialer. Den ikkeoffentlige information er fortrinsvis blevet indsamlet og registreret på baggrund af oplysninger, som kunne indhentes $i$ lokale vejvisere og den lokale presse, det drejer sig især om foreninger og private rådgivningscentre. Desuden har man registreret borgergrupper af forskellig art via de lokale medier. Indsamling af disse oplysninger har krævet en aktiv indsats fra biblioteket, dog som regel uden en egentlig politik på området. Registreringen har oftest være udført manuelt, men enkelte steder, $f$. eks. Lyngby og Århus er der blevet etableret en database med disse oplysninger. Flere steder har man skabt mulighed for kommunikation mellem enkelte borgere eller grupper af borgere i lokalområdet ved at etablere oplagstavler eller lignende, hvor alle i princippet havde mulighed for at udveksle oplysninger.

Denne model for indsamling, registrering og formidling er kun i begrænset omfang brugbar i fremtiden. Baggrunden herfor er dels den teknologiske udvikling dels (på baggrund heraf) en række oplæg, diskussioner og tiltag på det statslige niveau, som făr direkte indflydelse på, hvilken rolle det lokale folkebibliotek skal spille i den fremtidige formidling af både den offentlige information og information om samfundsforhold $i$ øvrigt.

\section{Info-samfundet år 2000}

Info-2000-rapporten (2) er dels et oplæg til regeringen, hvori der bliver tegnet et billede af danskernes muligheder i informationssamfundet og set på indsatsområder for den nærmeste fremtid, dels et oplæg til debat på en række områder, herunder anvendelse af informationsteknologien til gavn for den økonomiske udvikling, forbedring af den offentlige service og en forbedret livskvalitet. Hertil kommer et ønske om en diskussion af trusler og muligheder for demokratiet i informationssamfundet. Det blev bl.a. præciseret af daværende kulturminister Jytte Hilden, at demokratiet hviler på den enkelte borgers lige og frie adgang til information $o g$ at viden modvirker tendenser til polarisering $i$ samfundet. Målet for anvendelsen af teknologien bliver derfor en bedre kommunikation mellem samfund og borger. Det er således modeller for denne kommunikation, der skal danne grundlag for anvendelsen af teknologien i modsætning til en teknologisk styring af kommunikationen.

\section{Handlingsplaner}

Info-2000 rapporten er siden blevet fulgt op af foreløbig 3 handlingsplaner (3). I disse handlingsplaner udpeges de områder, hvor der skal ske ændringer med henblik på moderniseringen af den offentlige sektor, f.eks. elektronisk sagsbehandling og arkivering, sammenbinding af hele den offentlige forvaltning $i$ et elektronisk servicenet og lignende, hvilket er forudsætningen for, at adgangen til den offentlige information bliver lettere. Elektronisk kundgørelse $\mathrm{i}$ Lovtidende, Ministerialtidende og Statstidende samt modernisering af Retsinformation er projekter, som ligeledes er blevet fremlagt $\mathbf{i}$ handlingsplanerne. Målet er en åben offentlig sektor, med åbne forvaltninger og elektronisk service, samtidig med, at det skal være muligt for den 
enkelte at få overblik over den offentlige information.

Bibliotekernes rolle påpeges specielt med henblik på at sikre den frie tilgængelighed til de offentlige informationer. Men de er ikke de eneste distributører, de såkaldte 'kvikskranker' ${ }^{3}$ på rådhusene spiller også en rolle som distributionssted. Endvidere er det tanken, at der på offentlige steder som posthuse, rådhuse, biblioteker, evt. en lokal købmand, hvis han er eneste 'offentlige rum' i et lokalsamfund, skal opstilles 'infokiosker', som kan give borgere, der ikke hjemme har computer med modem, adgang til den offentlige elektroniske information. Fra et offentligt synspunkt vurderes det, at 'infokioskerne' vil give bibliotekerne mulighed for at give adgang til nogle nye informationsog serviceydelser, hvoraf de statslige vil blive produceret centralt og de lokale i kommunen, evt. i samarbejde med biblioteket. Internet vurderes at være det centrale medie i kommunikationen mellem borgeren og det offentlige. Det får en fremtrædende plads $i$ forbindelse med moderniseringen af den offentlige sektor, hvilket bl.a. betyder at alle publikationer, som skønnes at have interesse for den brede befolkning skal formidles via Internet. Internet skal give borgerne adgang til den offentlige information, give dem mulighed for at komme $\mathrm{i}$ dialog med det offentlige og endelig give dem adgang til en række selvbetjeningssystemer, f.eks. indtastning af tal til selvangivelsen og lignende.

\section{Offentlig informationspolitik}

I forlængelse af Info-2000 rapporten og handlingsplanerne udkom i efteråret 1997 en betænkning om en offentlig informationspolitik, (4) som tager udgangspunkt $i$ undersøgelser af borgerne fra forskellige vinkler. Baggrundén er dels, at der ikke tidligere $^{4}$ har været fokuseret på de forskelle blandt brugerne af den offentlige information, som har betydning for, hvordan formidlingen skal foregå, dels at borgerne $\mathrm{i}$ informationssamfundet forventes at have nogle andre behov end $i$ industrisamfundet. Man er således opmærksom på, at de på den ene side føler sig som enkeltindivider uden den klasse- følelse, som tidligere var almindelig og at de optræder i skiftende fællesskaber, afhængig af holdninger, beskæftigelse, sociale, religiøse og etniske forhold. Undersøgelser viser også, at borgerne kan kategoriseres efter livsværdier ${ }^{5}$ som er afgørende for, hvor tilbøjelige de f.eks. er til at anvende den ny teknologi. Denne viden er naturligvis nødvendig for formidlingen af den offentlige information, når målet $\mathrm{er}$ at nå alle borgere. I betænkningen bliver der ligeledes redegjort for fornyelsen af hele det offentlige system, som i langt højere grad $i$ informationsamfundet end $i$ industrisamfundet skal levere individuelle ydelser og individuelt tilpasset information til borgerne. Dette skal ske gennem flade organisationsstrukturer med bedre kommunikation og kommunikation på tværs internt i de offentlige institutioner, og eksternt gennem bedre kommunikation med borgerne, bl.a. ved hjælp af elektronisk selvbetjening. Der bliver sat fokus på større brugertilfredshed og produktion af information, som giver borgerne mere viden og dermed et bedre grundlag at handle på. Det skal være medvirkende til at skabe en større accept af hele det offentlige system og en bedre forståelse for hele samfundsstrukturen, i sidste ende et forsøg på at modvirke konflikter. Den information, som det offentlige producerer, skal ændres i indhold og struktur og være udarbejdet på brugerens præmisser. Betænkningen skal således ses som et oplæg til holdningsændringer $\mathrm{i}$ de offentlige institutioner. Betænkningen pålægger de statslige institutioner at arbejde målbevidst med formidlingen af information, mens der for de kommunale institutioners vedkommende kun er tale om anbefalinger. Formidlingen af den offentlige information skal ske på tværs af institutionsgrænser, der skal skabes en dialog mellem det offentlige og borgerne og der skal etableres et samarbejde mellem stat og kommune for at lette adgangen til den rigtige information. Målet er bedre information frem for mere information. Selvbetjening via de elektroniske medier og etablering af elektroniske rum, hvor borgerne både kan kommunikere med hinanden og med myndighederne er nogle af de forslag, som allerede er i gang. Hertil kommer forslag om formidlere, som skal hjælpe borgerne, dels med at få informationerne, dels med at forstå dem. 
Der er tale om 4 forskellige typer formidlere:

* Professionelle formidlere: referencebibliotekarer, folkeskolelærere

* Professionelle fortolkere: socialrådgivere, handicapkonsulenter, sagbehandlere i faglige organisationer

* Formidlere og fortolkere: praktiserende læger, kvikskrankepersonale

* Oversættere: hjemmehjælpere

\section{Folkebibliotekerne og den offentlige information}

Bibliotekernes rolle i formidlingen har to dimensioner. Den første er distribution af publikationer, hvor det fastslås, at alle statslige publikationer skal findes på centralbibliotekerne og at alle publikationer fra kommunen skal findes på et hvert bibliotek i kommunen. Den kommunale pligtaflevering skal fungere bedre end hidtil.

Den anden dimension er rådgivning til borgerne $\mathrm{i}$ form af øgede muligheder for hjælp til at kunne overskue deres problem. Bibliotekerne er imidlertid ikke alene om denne opgave, hjemmeplejen, frivillige organisationer og pensionistcentre er andre aktører i denne rolle, som det også fremgår af ovennævinte oversigt over formidlere. Der lægges imidlertid vægt på, at bibliotekerne forlader den traditionelle rolle, som distributionssted og det sted, hvor man får hjælp til at finde information og i stedet bliver det sted, hvor man via Internet og 'infokiosker' kan få direkte adgang til den offentlige information.

\section{Hvordan skal bibliotekerne lose denne opgave ?}

Der er, som det fremgår af ovennævnte rapporter og betænkning, ændrede forudsætninger for formidlingen af samfundsinformation i folkebibliotekerne. Vi har fảet et politisk grundlag for arbejdet med formidling af den offentlige information. Der er samtidig blevet nævnt nogle konkrete eksempler på, hvordan nogle af disse formidlingsopgaver tænkes løst. Dem skal vi arbejde med, men vi skal også selv gøre os klart, hvad vi kan og vil og ikke mindst selv være udfarende og udarbejde forslag til, hvordan formidlingen af samfundsinformation ikke blot i biblioteket, men i kommunen kan/bør foregå i fremtiden.

\section{Infokiosker}

Det forventes, at de såkaldte infokiosker vil blive tilbudt alle kommuner i den nærmeste fremtid (sandsynligvis i 1998). Disse infokiosker skal placeres på offentligt tilgængelige steder: folkebiblioteket, rådhuset, posthuset, og lign. Borgerne skal via computere herfra kunne få adgang til serviceoplysninger fra de offentlige myndigheder, f. eks. fra Statens Information, ministerier m.v. og fra det lokale niveau vil det være oplysninger fra forvaltningen, referater fra kommunalbestyrelsens møder, lokalplanforslag m.v. Kioskejeren, som kan være enten kommunen eller biblioteket, bestemmer hvilke informationer, der skal være adgang til. Det er derfor vigtigt, at bibliotekerne i forlængelse af den tradition, de har i formidlingen af samfundsinformation påtager sig denne opgave i samarbejde med kommunen.

\section{Internet}

Betænkningen fremhæver Internet, som den centrale kanal for offentliggørelsen af publikationer og informationer fra de offentlige institutioner og myndigheder når det drejer sig om love, serviceinformation $o g$ anden bearbejdet information rettet mod bestemte målgrupper. På statsligt niveau er der tiltag til etablering af centrale indgange, som gør det lettere for borgerne at finde rundt $\mathrm{i}$ det offentlige system. Danmark.dk er et godt eksempel herpå, selv om vi endnu ikke har set den i funktion. Samfundsnøglen er indtil videre det bedste eksempel på, at det kan lade sig gøre at formidle information på tværs af institutionsgrænser og -niveauer. Den kommunale information forventes ligeledes $\mathrm{i}$ stort omfang at blive formidlet via Internet, hvor det især drejer sig om referater fra møder og oplysninger om politikere, lige som oplysninger om kommunale institutioner m.v. vil blive tilgængelig ad denne vej. Distribution af aktuel information, f.eks. vedr. valg er taget $i$ brug ved kommunalval- 
get november 1997 og vil utvivlsomt fortsætte ved kommende valg. Kommunikation med politikere og ansatte både på det kommunale og statslige niveau vil blive muligt $i$ langt højere grad end det er tilfældet endnu via Internet, og adgang til selvbetjening på en række områder vil blive udbygget. Kommunikationen mellem borgerne skal også kunne ske via Internet via etablering af offentlige diskussionsfora, hvor borgerne kan kommentere samfundsforhold eller andre aktuelle problemstillinger. Vedrørende information om samfundsforhold $\mathrm{i}$ ørigt forventes det, at både lokale, nationale og globale organisationer og foreninger fortsat vil udnytte de muligheder, der er i Internet med hensyn til at informere og få deres budskab ud til borgerne.

\section{Lokale indgange}

Folkebibliotekerne kan ikke alene bruges som det sted, hvor der findes adgang til nettet for dem, som endnu ikke har det, således som det fremgår af betænkningen, men også som den virtuelle indgang til samfundsinformation. Biblioteket får mulighed for at markere sig som samarbejdspartner for kommunen, samtidig med, at det får mulighed for at markere sig over for kommunens borgere som indgangen til samfundsinformation, hvadenten det drejer sig om den lokale, den nationale eller globale samfundsinformation. Selv om der på centralt niveau f.eks. af Statens Information bliver udarbejdet indgange til den offentlige information til brug for alle, vil det imidlertid være nødvendigt at supplere med lokale indgange, som ikke alene fokuserer på den offentlige information, men som også inddrager den ikke offentlige information $i$ en samlet oversigt over information i relation til de problemområder, som borgerne ønsker belyst. Det vil endvidere være muligt at medtage information fra forskellige kilder om aktuelle emner, som debatteres lokalt. De ressourcer, der skal anvendes på udarbejdelsen af disse lokale indgange må frigøres til formålet gennem rationaliseringer på andre områder. En informationsguide til lokalsamfundet bliver både et vigtigt led $i$ formidlingen og et nødvendigt internt arbejdsredskab for bibliotekarerne.

\section{Design af offentlige Web-sider (5)}

En aktiv formidling af samfundsinformation $i$ fremtiden indebærer et kritisk og omhyggeligt arbejde med design. Udgangspunktet for design er at udarbejde en service, som er i overensstemmelse med brugernes opfattelse af biblioteket og deres egne behov. Det er nødvendigt at tilgodese de differentierede behov, som findes hos brugerne, frem for at præsentere en service, som et bygget op omkring bibliotekets selvopfattelse. Lange lister over informationer er ikke særligt velegnede for brugerne, og en emneingang, som blot forer ind til en liste er ikke optimalt. Søgemaskiner er ikke alene løsningen, hvis man ikke kender terminologien og lign. Som regel vil en kombination af en god emneindgang med mulighed for browsing i emnekategorier og en søgefacilitet kunne dække de fleste brugeres behov.

\section{Konklusion}

Allerede i planlægningsfasen må biblioteket sikre, at de holdninger, som hidtil har ligget til grundlag for bibliotekets formidling fortsat vil komme til udtryk i både udvalget af informationer og i selve formidlingen af dem. I relation til borgerne er det vigtigt at påpege, at det lokale bibliotek har borgernes tillid, således som det også fremgår af betænkningen om den offentlige informationspolitik. Det bliver opfattet som uafhængigt af den offentlige forvaltning og administration, idet det er muligt her at fă adgang til informationer, der kan belyse de rettigheder, som borgeren har i forhold til det offentlige system. Biblioteket skal stadig være det sted, hvor det er muligt at få personlig vejledning til at kunne finde de rette informationer. Men i fremtiden vil det også være bibliotekets opgave at udvælge og formidle informationer om samfundsforhold via Internet og 'infokiosker'.

Målet må være, at borgerne ved, at de, i det øjeblik, de bruger biblioteket, uanset om det foregår $\mathrm{i}$ det fysiske bibliotek eller virtuelt som indgang til Internet-ressourcer, har en garanti for, at der er foretaget en udvælgelse af disse ressourcer på bag- 
grund af kvalificerede søgninger i overensstemmelse med lovens ord om kvalitet, alsidighed og aktualitet. Biblioteket skal desuden være en aktiv formidler ved at udarbejde korte, præcise annotationer rettet mod brugerne, som giver dem mulighed for selv at foretage den endelige udvælgelse af informationskilden til det aktuelle informationsbehov. Biblioteket vil med løsningen af denne opgave få øgede muligheder for at markere sig i lokalsamfundet, og hermed understrege, at det specielt $\mathrm{i}$ relation til samfundsinformation har en særlig rolle og forpligtelse.

\section{Noter}

1. Samfundsinformation i folkebibliotekerne. Faggruppen for referencearbejde (1985): "Ved samfundsinformation forstås både den offentlige og ikke-offentlige information, som den enkelte borger eller gruppe af borgere har brug for, når denne ønsker at hævde sine interesser $\mathrm{i}$ politisk sammenhæng, at påvirke beslutningsprocesser samt at opretholde eller forbedre sine levevilkår. Med levevilkår tænkes der her især på sociale, økonomiske, boligmæssige og uddannelsesmæssige forhold."

2. Biblioteksloven 1983 formulerer det således i $\S$ 2: "Folkebibliotekerne skal formidle kommunal og statslig information og information om samfundsforhold i øvrigt"

3. Kvikskranker er informationsskranker, som er indrettet på rådhuse med frontpersonale, som skal kunne klare lettere informationsopgaver i relation til den primært lokale offentlige forvaltning. Formålet siges at være en bedre borgerservice, men er reelt etableret $i$ et forsøg på at spare penge, specielt personaleressourcer

4. Betænkninger om formidling af offentlig information

5. Minerva-segmenterne. Se Information til tiden. Bet. 1342. Bilag 1-7, s. $11 \mathrm{ff}$

\section{Litteratur}

(1) Samfundsinformation i folkebibliotekernedefinition, erfaringer og krav (1985). - Faggruppen for referencearbejde

(2) Info-samfundet år 2000 (1994). - Rapport fra udvalget om 'Informationssamfundet år 2000'. Forskningsministeriet

(3) Fra vision til handling. Info-samfundet år 2000 (1995). - Redegørelse til Folketinget om Info-samfundet år 2000 og IT-politisk handlingsplan. Forskningsministeriet.

Info-samfundet for alle - den danske model (1996). - IT-politisk redegørelse 1996 til Folketinget og IT-politisk handlingsplan 1996. Forskningsministeriet.

Handling gi'r forvandling (1997). - IT-politisk handlingsplan 97/98. Forskningsministeriet

(4) Information til tiden (1997). - Betænkning nr. 1342. Udvalget om offentlig informationspolitik. Forskningsministeriet.

(5) Johnson, Julie (1996). - Government Web pages: The light is on but nobody is home. - I: The Electronic Library. Vol. 14, 2, pp. 149156 